\title{
Pengaruh Pemberian Tepung Kulit Pisang Kepok Fermentasi + Feed Supplement terhadap Berat dan Persentase Karkas Ayam Broiler
}

\author{
(Effect of Using Fermented Banana Peel + Feed Supplement \\ on the Weight and Percentage of Broiler Chicken Carcass)
}

\author{
Rismanda Sari ${ }^{1}$, Herawati Latif ${ }^{1}$, Zulfan $^{1}$ \\ Program Studi Peternakan, Fakultas Pertanian, Universitas Syiah Kuala
}

\begin{abstract}
Abstrak: Tujuan penelitian ini adalah untuk mengetahui pengaruh substitusi sebagian ransum komersil periode finisher dengan tepung kulit pisang kepok (Musa paradisiaca normalis) fermentasi + bungkil kelapa + feed supplement terhadap berat dan persentase karkas ayam broiler. Penelitian dilakukan di Laboratorium Lapangan Peternakan (LLP), Fakultas Pertanian, Universitas Syiah Kuala, tanggal 1 April-5 Mei 2016. Penelitian menggunakan 100 ekor anak ayam broiler (DOC) strain lohmann. Perlakuan yang dicobakan adalah pemberian tepung kulit pisang kepok fermentasi + bungkil kelapa + feed supplement sebanyak $0 \%\left(\mathrm{P}_{1}\right), 2,5 \%+1,5 \%+1 \%$ $\left(\mathrm{P}_{2}\right), 5 \%+3 \%+1 \%\left(\mathrm{P}_{3}\right) .7,5 \%+4,5 \%+1 \%\left(\mathrm{P}_{4}\right)$, dan $10 \%+6 \%+1 \%\left(\mathrm{P}_{5}\right)$. Parameter yang diamati meliputi berat dan persentase karkas, potongan karkas, dan giblets. Hasil penelitian memperlihatkan bahwa substitusi ransum komersil dengan tepung kulit pisang kepok fermentasi sebanyak 10\% + bungkil kelapa 6\% + feed supplement $1 \%$ tidak berpengaruh nyata $(\mathrm{P}>0,05)$ terhadap berat karkas, potongan karkas, serta organ giblets, namun nyata $(\mathrm{P}<0,05)$ berpengaruh terhadap persentase karkas ayam broiler. Meskipun secara statistik tidak berbeda nyata, ayam-ayam broiler yang diberikan tepung kulit pisang kepok fermentasi + bungkil kelapa + feed supplement umumnya memiliki bobot dan persentase dada relatif lebih tinggi dan bobot dan persentase punggung dan sayap lebih rendah dibandingkan dengan ayam broiler yang diberikan 100\% ransum komersil, sedangkan bobot dan persentase paha relatif sama pada semua perlakuan.
\end{abstract}

Kata Kunci: broiler, karkas, pisang, fermentasi

\begin{abstract}
The aim of present study was to determine effect of partial substitution of commercial broiler finisher ration with a fermented banana (Musa paradisiaca normalis) peel + coconut meal + feed supplement to the weight and the percentage of broiler chicken carcasses. The study was conducted in Field Laboratory, Livestock Department, Faculty of Agriculture, Syiah Kuala University, April 1 until Mei 5, 2016. As many as 100 chicks, strain lohmann. The treatment was the provision of fermented banana peel + coconut meal + feed supplement with the level of $0 \%\left(\mathrm{P}_{1}\right), 2,5 \%+1,5 \%+1 \%\left(\mathrm{P}_{2}\right), 5 \%+3 \%+1 \%\left(\mathrm{P}_{3}\right) .7,5 \%+4,5 \%+1 \%\left(\mathrm{P}_{4}\right)$, and $10 \%+6 \%+1 \%\left(\mathrm{P}_{5}\right)$, respectively. The parameters observed were the weight and percentage of carcass, retail cut-ups, and giblets. The results of study showed that administration of up to $10 \%$ fermented banana peel $+6 \%$ coconut meal $+1 \%$ feed supplement as partial substitution of commercial finisher broiler ration was not significant effect $(\mathrm{P}>0.05)$ on the weight of carcass, retail cut-ups and gilblets. However, carcass percentage was significantly effect $(\mathrm{P}<0.05)$. Although, statiscally no significant effect, the percentage of breast tend to higher while the percentage of back tend to lower found in the chickens fed on the substitution rations
\end{abstract}

Key words: broiler, carcass, fermentation, banana peel

\section{PENDAHULUAN}

Kendala utama dalam pemeliharaan ayam broiler adalah biaya ransum yang dapat mencapai $65-70 \%$ dari total biaya produksi. Bahan penyusun ransum ayam broiler sebagian besar berupa bahan pangan dan ikutannya seperti jagung, bungkil kedelai, bungkil kelapa, dan tepung ikan. Jumlah kebutuhan akan bahan-bahan ini lebih tinggi dari pada ketersediaannya, mengakibatkan adanya impor dari negara lain. Hal inilah yang menyebabkan harga ransum menjadi relatif tinggi. Untuk mengatasi masalah ini maka perlu pemanfaatan bahan-bahan penyusun ransum inkonvensional, seperti, limbah pertanian. Salah satu limbah pertanian yang belum digunakan secara maksimal adalah kulit pisang.

Kulit pisang, bagian terluar dari buah pisang, tidak dikonsumsi oleh manusia. Kulit pisang umumnya dimanfaatkan untuk makanan kambing, domba, dan sapi. Kulit pisang sangat jarang digunakan untuk makanan unggas karena memiliki tekstur yang kasar dan 
kandungan serat kasar yang tinggi. Akan tetapi, kulit pisang ini bukan tidak mungkin dapat dijadikan sebagai bahan pakan unggas, setelah mengalami proses pengolahan terlebih dahulu. Hasil penelitian Koni (2013) memperlihatkan bahwa penggunaan tepung kulit pisang kepok yang difermentasi menurunkan berat karkas ayam broiler, namun persentase karkas tidak menurun sampai penggunaan 10\%. Pembatas lain penggunaan tepung kulit pisang ini adalah kandungan protein yang rendah, yakni 3,63\% (Koni, 2009).

Berdasarkan permasalahan tersebut maka penggunaan tepung kulit pisang sebaiknya dicampur dengan bahan pakan lain yang mengandung protein lebih tinggi, harganya murah, dan mudah diperoleh. Salah satu bahan pakan dimaksud adalah bungkil kelapa. Bungkil kelapa merupakan hasil sampingan dari pabrik minyak kelapa. Bungkil kelapa tidak sulit diperoleh di Aceh dan harganya pun relatif murah. Meskipun tidak setinggi pada bungkil kedele, kandungan protein pada bungkil kelapa masih cukup tinggi (sekitar 21\%) dan hampir sama dengan kandungan protein dalam ransum komersil (Wahyu, 1992). Penggunaan bungkil kelapa ini dimaksudkan untuk menaikkan kembali kandungan protein dalam ransum komersil yang berkurang sebagai akibat dari penggunaan tepung kulit pisang.

Untuk mencukupi zat-zat gizi lainnya, terutama vitamin, mineral, dan asam amino di dalam ransum substitusi, maka perlu ditambahkan bahan pelengkap (feed supplement). Feed supplement merupakan bahan makanan berupa campuran preparat vitamin, mineral, dan antibiotika guna melengkapi ransum (Sudaryani dan Santoso, 2003). Berdasarkan uraian di atas maka dilakukan penelitian penggunaan tepung kulit pisang kepok fermentasi + bungkil kelapa + feed supplement sebagai substitusi sebagian ransum komersil untuk melihat pengaruhnya terhadap berat dan persentase karkas ayam broiler. Tujuan penelitian ini adalah untuk mengetahui pengaruh substitusi sebagian ransum komersil periode finisher dengan tepung kulit pisang kepok fermentasi (Musa paradisiaca normalis) + bungkil kelapa + feed supplement terhadap berat dan persentase karkas ayam broiler.

\section{MATERI DAN METODE}

\section{Tempat dan Waktu Penelitian}

Penelitian ini dilakukan di Laboratorium Lapangan Peternakan (LLP), Program Studi Perternakan, Fakultas Pertanian, Universitas Syiah Kuala, Banda Aceh tanggal 1 April-5 Mei 2016.

\section{Materi Penelitian}

Materi yang digunakan dalam penelitian ini adalah anak ayam broiler (DOC) sebanyak 100 ekor, strain loghmann.

\section{Bahan dan Alat Penelitian}

Bahan yang digunakan dalam penelitian ini terdiri dari ransum komersil broiler, kulit pisang kepok, ragi tape, bungkil kelapa, feed supplement (top mix), vitachick, vitastress, vaksin, desinfektan, kapur, litter, dan kantung plastik. Peralatan yang digunakan terdiri dari timbangan digital, tempat pakan, tempat minum, bola lampu pijar, nampan, dandang, kukusan, disc mill, dan alat peniris.

\section{Ransum Perlakuan}

Penelitian ini menggunakan ransum dasar berupa ransum komersil broiler 511 dan 512 Bravo. Ransum 511 Bravo digunakan selama masa starter (0-3 minggu), sedangkan ransum 512 Bravo digunakan selama masa finisher (4-5 minggu). Ransum komersil 512 Bravo 
sebagian disubstitusi dengan 2,5-10\% tepung kulit pisang kepok fermentasi + 1,5-6,0\% bungkil kelapa $+1,0 \%$ feed supplement. Ransum perlakuan adalah sebagai berikut:

$\mathrm{P}_{1}$ : Ransum komersil broiler 512 Bravo 100\% + tepung kulit pisang fermentasi $0 \%+$ bungkil kelapa $0 \%$ (kontrol) + feed supplement $0 \%$.

$\mathrm{P}_{2}$ : Ransum komersil broiler 512 Bravo 95,0\% + tepung kulit pisang fermentasi 2,5\% + bungkil kelapa 1,5\% + feed supplement 1,0\%.

$\mathrm{P}_{3}$ : Ransum komersil broiler 512 Bravo 91.0\% + tepung kulit pisang fermentasi 5.0\% + bungkil kelapa 3,0\% + feed supplement 1,0\%.

$\mathrm{P}_{4}$ : Ransum komersil broiler 512 Bravo 87.0\% + tepung kulit pisang fermentasi 7,5\% + bungkil kelapa $4,5 \%+$ feed supplement $1,0 \%$.

$\mathrm{P}_{5}$ : Ransum komersil broiler 512 Bravo $83 \%$ + tepung kulit pisang fermentasi 10,0\% + bungkil kelapa $6,0 \%+$ feed supplement $1,0 \%$.

Tabel 1. Susunan dan Kandungan Zat Gizi Ransum Penelitian

\begin{tabular}{|c|c|c|c|c|c|}
\hline \multirow[b]{2}{*}{ Bahan Pakan } & \multicolumn{5}{|c|}{$\begin{array}{c}\text { Ransum Komersil Broiler Disubstitusi dengan Tepung Kulit Pisang Kepok } \\
\text { Fermentasi + Bungkil Kelapa + Feed Supplement }\end{array}$} \\
\hline & $\mathrm{P}_{1}$ & $\mathrm{P}_{2}$ & $\mathrm{P}_{3}$ & $\mathrm{P}_{4}$ & $\mathrm{P}_{5}$ \\
\hline 512 Bravo*) & 100 & 95,0 & 91,0 & 87,0 & 83,0 \\
\hline Tepung Kulit Pisang & 0 & 2,5 & 5,0 & 7,5 & 10,0 \\
\hline \multicolumn{6}{|l|}{ Kepok Fermentasi ${ }^{* * *}$} \\
\hline Bungkil Kelapa ${ }^{* * *)}$ & 0 & 1,5 & 3,0 & 4,5 & 6,0 \\
\hline Feed Supplement & 0 & 1,0 & 1,0 & 1,0 & 1,0 \\
\hline Jumlah & 100 & 100 & 100 & 100 & 100 \\
\hline \multicolumn{6}{|c|}{ Kandungan Zat Gizi Berdasarkan Perhitungan } \\
\hline Protein $(\%)$ & $19,00-21,50$ & $18,97-21,34$ & $19,13-21,40$ & $19,29-21,46$ & $19,45-21,52$ \\
\hline Serat Kasar (\%) (max) & 5,00 & 5,39 & 5,85 & 6,28 & 6,73 \\
\hline Lemak Kasar (\%) (min) & 5,00 & 4,86 & 4,77 & 4,67 & 4,58 \\
\hline $\mathrm{Ca}(\%)(\min )$ & 0,90 & 1,05 & 1,20 & 1,36 & 1,52 \\
\hline $\mathrm{P}(\%)(\min )$ & 0,60 & 0,65 & 0,70 & 0,76 & 0,81 \\
\hline
\end{tabular}

Ransum penelitian dibagi menjadi 5 bagian; bagian pertama tidak ditambahkan tepung kulit pisang fermentasi + bungkil kelapa + feed supplement, sebagai perlakuan $\mathrm{P}_{1}$ (kontrol). Bagian kedua sampai kelima ransum perlakuan ditambahkan tepung kulit pisang fermentasi + bungkil kelapa + feed supplement sebanyak masing-masing 2,5+1,5+1,0\%, 5,0+3,0+1,0\%, $7,5+4,5+1,0 \%$, dan $10,0+6,0+1,0 \%$ sebagai perlakuan $\mathrm{P}_{2}, \mathrm{P}_{3}, \mathrm{P}_{4}$, dan $\mathrm{P}_{5}$. Selanjutnya, ransum perlakuan tersebut diberikan pada ayam broiler.

\section{Pembuatan Tepung Kulit Pisang Fermentasi}

Proses pembuatan tepung kulit pisang fermentasi dilakukan dengan prosedur sebagai berikut: (1) kulit pisang kepok dikumpulkan dari penjual pisang goreng, (2) dipotong kecilkecil dengan ukuran $\pm 5 \mathrm{~cm}$, (3) dicuci, (4) dikukus selama \pm 25 menit untuk mematikan kuman pathogen, (5) diangin-anginkan, (6) dicampur ragi sebanyak $3 \mathrm{~g} / \mathrm{kg}$ kulit pisang, (7) dibungkus di dalam kantung plastik tidak padat agar jamur dapat tumbuh optimum selama empat hari, (8) disimpan pada suhu kamar selama 48 jam, dan (9) dikeringkan, dan (10) digiling hingga menjadi tepung. Kandungan gizi tepung kulit pisang sebelum dan sesudah fermentasi diperlihatkan pada Tabel 2. 
Tabel 2. Kandungan Gizi Tepung Kulit Pisang Sebelum dan Sesudah Fermentasi

\begin{tabular}{lcc}
\hline Zat Gizi & Sebelum Fermentasi & Setelah Fermentasi \\
\hline Protein Kasar (\%) & 3,63 & 22,15 \\
Serat Kasar $(\%)$ & 18,71 & 15,75 \\
Lamak Kasar $(\%)$ & 2,52 & 2,63 \\
Ca $(\%)$ & 7,18 & 7,59 \\
P $(\%)$ & 2,06 & 2,75 \\
\hline
\end{tabular}

Sumber: Koni (2009)

\section{Rancangan Penelitian}

Rancangan penelitian yang digunakan adalah Rancangan Acak Kelompok dengan subsampel (block randomized design with subsamples) terdiri dari 5 perlakuan, 5 kelompok, dan 2 subsampel. Setiap kelompok merupakan unit percobaan yang terdiri dari lima ekor ayam sehingga total ayam seratus ekor. Perlakuan yang diberikan adalah penggunaan ransum komersil broiler 512 Bravo yang sebagian disubstitusi dengan tepung kulit pisang fermentasi + bungkil kelapa + feed supplement dengan taraf berbeda.

Model matematika penelitian yang digunakan menurut Steel dan Torrie (1993) adalah:

Keterangan:

$Y_{i j k}=\mu+\tau_{i}+\beta_{j}+\varepsilon_{i j}+d_{i j k}$

$Y_{i j k} \quad$ : Nilai pengamatan

$\mu \quad$ : Nilai tengah umum

$\tau_{i} \quad$ : Pengaruh percobaan ke- $i$

$\beta_{j} \quad$ : Pengaruh kelompok ke-j

$\varepsilon_{i j} \quad:$ Pengaruh galat percobaan ke- $i$ ulangan ke-j

$d_{i j k} \quad$ : Pengaruh galat percobaan ke- $i$ ulangan ke-j, subsampel ke- $k$

\section{Parameter Penelitian}

Parameter yang diamati dalam penelitian ini meliputi berat dan persentase karkas, berat dan persentase potongan karkas (paha, dada, sayap, dan punggung), dan berat dan persentase giblet (hati, rempela, dan jantung).

\section{Pelaksanaan Penelitian}

Penelitian ini dilakukan dalam tiga tahap, yaitu:

a. Tahap Persiapan

Tahap persiapan terdiri dari persiapan kandang dan ransum. Persiapan kandang meliputi pembersihan kandang, sanitasi kandang (dalam dan sekitar kandang), pencucian, penyemprotan desinfektan, pengapuran, persiapan tempat pakan dan tempat minum, serta pembuatan unit-unit percobaan. Unit percobaan dibuat sebanyak 20 buah, masing-masing berukuran $70 \times 70 \mathrm{~cm}$. Tiap unit percobaan dilengkapi dengan pemanas berupa bola lampu pijar dengan daya 40 watt. Masing-masing unit percobaan diberi kode perlakuan secara acak.

Persiapan ransum meliputi formulasi ransum, pembuatan tepung kulit pisang fermentasi, dan pencampuran ransum. Formulasi ransum dilakukan berdasarkan perlakuan yang diberikan. Bahan-bahan penyusun, berupa ransum komersil, tepung kulit pisang fermentasi, bungkil kelapa, dan feed supplement. Pencampuran ransum dilakukan berdasarkan komposisi ransum yang dibuat, dilakukan pada awal minggu keempat dan kelima. Bahan suplemen lain yang digunakan berupa vitachick dan vitastress yang dibeli dari poultry shop. 


\section{b. Tahap Pemeliharaan}

Pemeliharaan dibagi ke dalam periode 0-3 minggu (starter) dan 4-5 minggu (finisher). Selama periode 0-3 minggu, ayam dari semua perlakuan diberikan seratus persen ransum komersil $R_{511}$. Selama periode 4-5 minggu, ayam dari perlakuan $P_{1}$ diberikan seratus persen ransum komersil $\mathrm{R}_{512}$, sedangkan perlakuan $\mathrm{P}_{2}-\mathrm{P}_{5}$, diberikan ransum komersil $\mathrm{R}_{512}$ yang disubstitusi dengan tepung kulit pisang fermentasi + bungkil kelapa sebanyak $4-12 \%+1 \%$. Ransum diberikan ad libitum dengan pemberian dua kali sehari, yaitu pukul 08.00 dan 17.00 WIB.

Vaksinasi yang dilakukan adalah ND dan Infectious Bursal Disease (gumboro). Vaksinasi ND dilakukan pada umur 3 hari via tetes mata dan diulangi pada umur 21 hari via suntikan intramuskuler. Vaksinasi gumboro dilakukan pada umur 12 hari via tetes mulut.

c. Tahap Pengambilan Data

Tahap pengambilan data dilakukan pada akhir penelitian (hari ke-35). Semua ayam ditimbang untuk mengetahui rata-rata berat badan akhirnya. Sebanyak dua ekor ayam diambil dari masing-masing unit percobaan dengan kriteria rata-rata berat badannya mendekati rata-rata berat badan unit percobaannya. Ayam selanjutnya dipotong, dikeluarkan darah, dicabut bulu, dibuang kepala dan leher, kaki serta jeroan sehingga diperoleh karkas. Lemak abdomen dipisahkan dari karkas, selanjutnya ditimbang. Karkas ditimbang untuk mengetahui beratnya, selanjutnya bagian-bagian karkas berupa paha, dada, sayap, dan punggung dipisahkan dan ditimbang untuk mengetahui berat masingmasing potongan karkas.

\section{Analisis Data}

Data yang diperoleh akan diolah secara statistik dengan menggunakan analysis of variance (ANOVA). Jika diantara perlakuan terdapat perbedaan yang nyata $\left(\mathrm{F}_{\text {hit }}>\mathrm{F}_{\text {tabel }}\right.$ $\alpha=0.05$ ) maka dilakukan uji lanjut dengan menggunakan Uji Jarak Berganda Duncan (Duncan Multiple Range Test) (Steel dan Torrie, 1993).

\section{HASIL DAN PEMBAHASAN}

\section{Berat dan Persentase Karkas Ayam Broiler}

Berat dan persentase karkas dan nonkarkas ayam broiler yang diberi ransum komersil yang sebagian disubstitusi dengan tepung kulit pisang kepok fermentasi + bungkil kelapa + feed supplement selama periode finisher (4-5 minggu) diperlihatkan pada Tabel 3. Hasil sidik ragam memperlihatkan bahwa substitusi sebagian ransum komersil dengan tepung kulit pisang kepok fermentasi + bungkil kelapa + feed supplement tidak berpengaruh nyata $(\mathrm{P}>0,05)$ terhadap berat karkas dan nonkarkas ayam broiler umur lima minggu, namun persentase karkas dan nonkarkas nyata berpengaruh $(\mathrm{P}<0,05)$.

Meskipun secara statistik tidak berbeda nyata, ayam-ayam broiler yang diberikan ransum komersil yang sebagian disubsitusi dengan tepung kulit pisang kepok fermentasi + bungkil kelapa + feed supplement $\left(\mathrm{P}_{2}-\mathrm{P}_{5}\right)$ selama periode finisher memiliki berat karkas sedikit lebih rendah dibandingkan dengan ayam tanpa diberikan bahan pakan substitusi tersebut $\left(\mathrm{P}_{1}\right)$. Menurut Soeparno (2009), berat karkas berkaitan dengan bobot badan, semakin tinggi bobot badan ternak maka semakin tinggi bobot karkas. Dalam penelitian ini, capaian bobot badan akhir ayam broiler dari semua perlakuan tidak jauh berbeda, kecuali pada penggunaan $10 \%$ tepung kulit pisang $\left(\mathrm{P}_{5}\right)$. Berdasarkan hal ini, faktor lain, seperti halnya, ransum secara tidak langsung juga akan berpengaruh terhadap bobot karkas. Ayamayam dengan nutrisi yang baik biasanya akan memiliki bobot karkas yang lebih baik. Ini 
berarti ransum substitusi memiliki nilai gizi yang tidak sebaik ransum komersial. Tepung kulit pisang memiliki nilai gizi yang lebih rendah, terutama kandungan serat kasar yang tinggi, dibandingkan dengan bahan-bahan pakan lain yang terdapat di dalam ransum komersil. Sesuai dengan Shahin dan Elazeem (2005), ransum yang mengandung serat kasar yang lebih tinggi menurunkan bobot karkas dibandingkan dengan ransum yang memiliki serat kasar yang lebih rendah.

Tabel 3. Berat dan Persentase Karkas dan Nonkarkas Ayam Broiler yang Diberi Perlakuan Tepung Kulit Pisang Kepok Fermentasi + Bungkil Kelapa + Feed Supplement

\begin{tabular}{|c|c|c|c|c|c|c|}
\hline \multirow{2}{*}{\multicolumn{2}{|c|}{$\begin{array}{l}\text { Berat Hidup dan } \\
\text { Karkas }\end{array}$}} & \multicolumn{5}{|c|}{$\begin{array}{c}\text { Pemberian Tepung Kulit Pisang Kepok Fermentasi + } \\
\text { Bungkil Kelapa }+ \text { Feed Supplement }\end{array}$} \\
\hline & & $\mathrm{P}_{1}$ & $\mathrm{P}_{2}$ & $\mathrm{P}_{3}$ & $\mathrm{P}_{4}$ & $\mathrm{P}_{5}$ \\
\hline Berat Hidup & (g) & $\begin{array}{l}1870,25 \\
\pm 250,82\end{array}$ & $\begin{array}{r}1810,13 \\
\pm 168,21\end{array}$ & $\begin{array}{r}1866,63 \\
\pm 141,76\end{array}$ & $\begin{array}{l}1870,00 \\
\pm 183,36\end{array}$ & $\begin{array}{r}1803,50 \\
\pm 218,27\end{array}$ \\
\hline Karkas & (g) & $\begin{array}{r}1393,63 \\
\pm 195,27 \\
74,47^{\mathrm{a}} \pm 1,20\end{array}$ & $\begin{array}{r}1332,00 \\
\pm 146,82 \\
73,49^{\mathrm{ab}} \pm 1,64\end{array}$ & $\begin{array}{r}1348,88 \\
\pm 119,81 \\
72,21^{\mathrm{b}} \pm 1,81\end{array}$ & $\begin{array}{r}1357,13 \\
\pm 141,90 \\
72,54^{\mathrm{ab}} \pm 1,86\end{array}$ & $\begin{array}{r}1316,63 \\
\pm 181,66 \\
72,88^{\mathrm{ab}} \pm 1,55\end{array}$ \\
\hline Nonkarkas & $\begin{array}{l}(\mathrm{g}) \\
(\%)\end{array}$ & $\begin{array}{r}476,63 \pm 60,67 \\
25,53^{\mathrm{a}} \pm 1,20\end{array}$ & $\begin{array}{r}478,13 \pm 32,32 \\
26,51^{\mathrm{ab}} \pm 1,64\end{array}$ & $\begin{array}{r}517.75 \pm 39.23 \\
27,12^{\mathrm{b}} \pm 1,81\end{array}$ & $\begin{array}{r}513.25 \pm 56.38 \\
27,46^{\mathrm{b}} \pm 1,86\end{array}$ & $\begin{array}{r}486.88 \pm 41.18 \\
27,79^{\mathrm{b}} \pm 1,55\end{array}$ \\
\hline
\end{tabular}

Penelitian Koni (2013) memperlihatkan penggunaan kulit pisang fermentasi $15 \%$ dalam ransum finisher menghasilkan bobot karkas paling rendah daripada penggunaan 0,5 , dan $10 \%$ kulit pisang fermentasi. Semakin tinggi penggunaan kulit pisang fermentasi semakin tinggi penurunan bobot karkas. Penurunan bobot karkas tersebut dikarenakan penurunan bobot badan akibat penurunan konsumsi ransum (Koni, 2013). Dugaan pengaruh bobot karkas akibat dari pemberian ransum dalam penelitian ini diperkuat dari nilai persentase karkas dan nonkarkas. Ayam-ayam yang diberi ransum yang mengandung tepung kulit pisang fermentasi memiliki persentase karkas lebih rendah dan persentase nonkarkas lebih tinggi. Penurunan persentase karkas nyata terlihat pada penggunaan 5\% tepung kulit pisang fermentasi $\left(\mathrm{P}_{3}\right)$. Meskipun kulit pisang yang digunakan telah difermentasi terlebih dahulu, kandungan serat kasar di dalam ransum diperkirakan masih cukup tinggi. Berdasarkan Koni (2013), kandungan serat kasar tepung kulit pisang kepok yang difermentasi 15,75\%, sedikit menurun dibandingkan sebelum difermentasi $(18,71 \%)$. Tambahan feed supplement di dalam ransum diperkirakan membantu mempertahankan bobot karkas ayam tidak nyata menurun.

Bahri dan Rusdi (2008) menambahkan bahwa serat kasar yang tinggi yang terkandung dalam kulit pisang akan menurunkan energi metabolis pakan, karena terjadinya penurunan kecernaan bahan, sehingga terjadi penurunan penyerapan zat-zat makanan. Tingkat energi metabolis berhubungan erat dengan kecernaan dan penyerapan zat-zat makanan. Hal ini sejalan dengan yang dilaporkan oleh McDonald et al. (1994) bahwa energi metabolisme ditentukan oleh kandungan dan keseimbangan zat makanan dalam bahan dan serat kasar merupakan faktor utama yang menentukan energi metabolisme.

Menurut Koni et al. (2013), walaupun terjadi peningkatan protein kasar pada kulit pisang kepok yang difermentasi, namun penggunaannya terbatas hingga $10 \%$ dalam ransum ayam pedaging. Bila digunakan lebih dari $10 \%$ (dalam hal ini 15\%) dapat menurunkan bobot badan. Budiansyah (2010) mengemukakan bahwa protein kasar bahan pakan hasil fermentasi sebagian terdiri dari fraksi asam nukleat yang berasal dari sel-sel mikroba, protein tersebut sulit dicerna oleh saluran pencernaan unggas sehingga ketersediaan protein untuk pertumbuhan berkurang. 

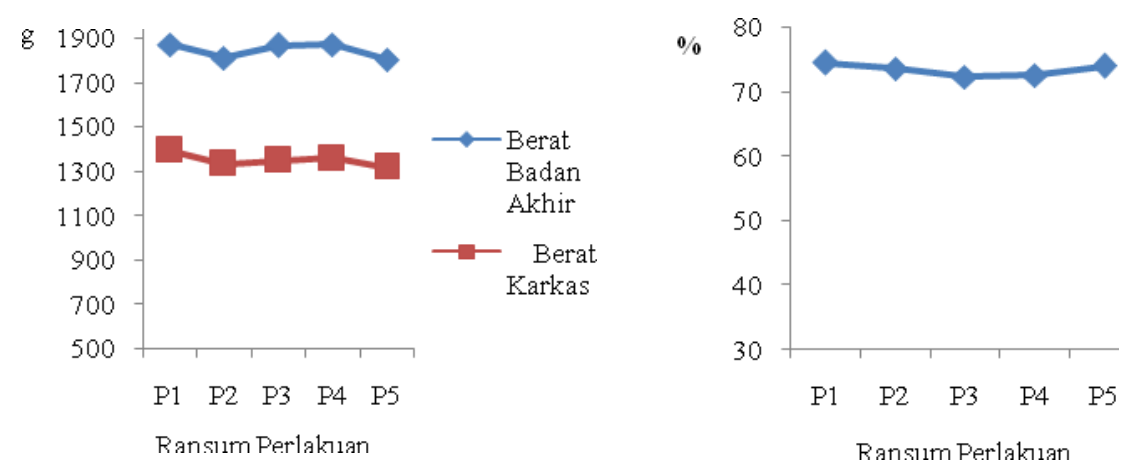

Gambar 1. Berat Badan, Berat dan Persentase Karkas Ayam Broiler dari Tiap Perlakuan Pemberian Tepung Kulit Pisang Kepok Fermentasi + Bungki Kelapa + Feed Supplement

\section{Berat dan Persentase Potongan Karkas Ayam Broiler}

Karkas dapat disediakan dalam bentuk karkas utuh (whole carcass) ataupun potonganpotongan karkas (retails cut-up). Secara ekonomis, potongan karkas ini memiliki nilai jual yang berbeda-beda. Dada (breast), paha (thighs), dan sayap (wings) memiliki nilai ekonomis yang lebih tinggi dibandingkan dengan punggung (back). Perbedaan ini dikarenakan perbedaan komponen daging di mana punggung memiliki daging yang lebih sedikit dibandingkan dengan potongan karkas lainnya. Berat dan persentase potongan karkas ayamayam broiler yang diberi ransum komersil yang sebagian disubstitusi dengan tepung kulit pisang kepok fermentasi + bungkil kelapa + feed supplement selama periode finisher pada akhir pemeliharaan lima minggu diperlihatkan pada Tabel 4.

Tabel 4. Berat dan Persentase Potongan Karkas Ayam Broiler yang Diberi Perlakuan Tepung Kulit Pisang Kepok Fermentasi + Bungkil Kelapa + Feed Supplement

\begin{tabular}{lrrrrrr}
\hline & \multicolumn{5}{c}{ Pemberian Tepung Kulit Pisang Kepok Fermentasi+ } \\
Potongan Karkas & \multicolumn{5}{c}{ Bungkil Kelapa + Feed Supplement } \\
\cline { 3 - 7 } (Retail cut-up) & & \multicolumn{1}{c}{$\mathrm{P}_{1}$} & \multicolumn{1}{c}{$\mathrm{P}_{2}$} & \multicolumn{1}{c}{$\mathrm{P}_{3}$} & \multicolumn{1}{c}{$\mathrm{P}_{4}$} & \multicolumn{1}{c}{$\mathrm{P}_{5}$} \\
\hline Dada (breast) & $(\mathrm{g})$ & $490,88 \pm 102,74$ & $480,38 \pm 88,03$ & $516,13 \pm 49,86$ & $521,88 \pm 60,80$ & $503,50 \pm 64,79$ \\
& $(\%)$ & $35,10 \pm 4,75$ & $35,84 \pm 2,83$ & $38,29 \pm 2,09$ & $38,45 \pm 1,79$ & $38,29 \pm 1,36$ \\
Paha (thighs) & $(\mathrm{g})$ & $400,13 \pm 63,18$ & $389,38 \pm 20,26$ & $373,88 \pm 45,28$ & $377,88 \pm 49,21$ & $375,50 \pm 66,50$ \\
& $(\%)$ & $28,70 \pm 1,72$ & $29,43 \pm 2,29$ & $27,67 \pm 1,42$ & $27,82 \pm 1,71$ & $28,44 \pm 1,71$ \\
Sayap (wings) & $(\mathrm{g})$ & $132,75 \pm 21,53$ & $124,00 \pm 15,07$ & $130,88 \pm 13,81$ & $128,13 \pm 8,81$ & $119,88 \pm 20,40$ \\
& $(\%)$ & $9,54 \pm 0,90$ & $9,32 \pm 0,72$ & $9,71 \pm 0,59$ & $9,49 \pm 0,76$ & $9,08 \pm 0,6$ \\
Punggung & $(\mathrm{g})$ & $369,88 \pm 87,06$ & $338,25 \pm 38,51$ & $328,00 \pm 31,39$ & $329,25 \pm 39,68$ & $317,75 \pm 39,21$ \\
& $\%)$ & $26,65 \pm 5,47$ & $25,41 \pm 1,27$ & $24,33 \pm 1,30$ & $24,23 \pm 1,07$ & $24,19 \pm 1,05$ \\
\hline
\end{tabular}

Hasil sidik ragam memperlihatkan bahwa pemberian tepung kulit pisang kepok fermentasi + bungkil kelapa + feed supplement selama periode finisher tidak berpengaruh nyata $(\mathrm{P}>0,05)$ terhadap berat semua potongan karkas ayam broiler. Meskipun secara statistik tidak berbeda nyata, ayam-ayam broiler yang diberikan tepung kulit pisang kepok fermentasi + bungkil kelapa + feed supplement $\left(\mathrm{P}_{2}-\mathrm{P}_{5}\right)$, umumnya, memiliki bobot dan persentase dada relatif lebih tinggi dan bobot dan persentase punggung dan sayap lebih rendah dibandingkan dengan ayam broiler yang diberikan seratus persen ransum komersil $\left(\mathrm{P}_{1}\right)$. Sedangkan, bobot dan persentase paha relatif sama pada semua perlakuan. 

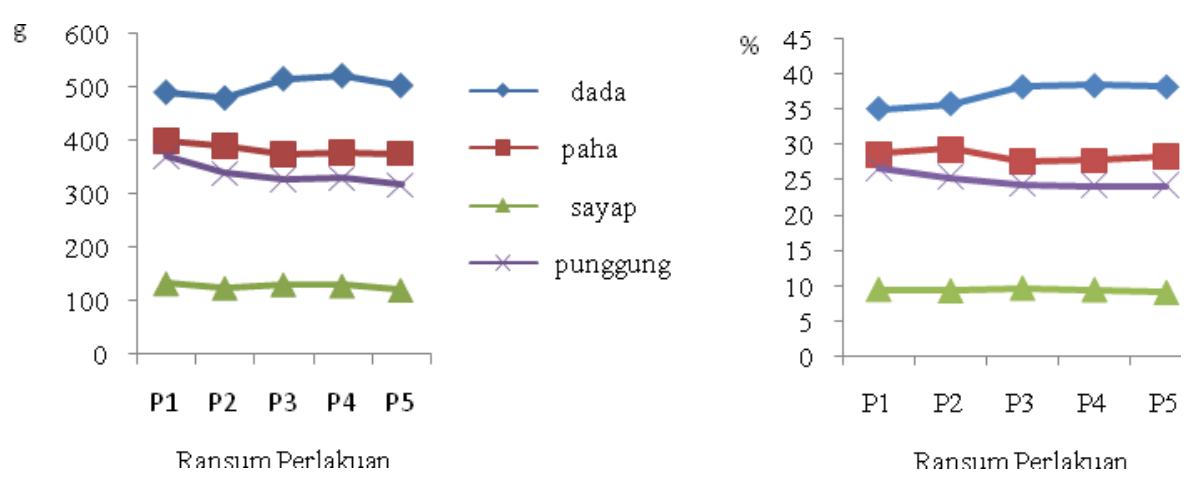

Gambar 2. Berat dan Persentase Potongan Karkas Ayam Broiler dari Tiap Perlakuan Pemberian Tepung Kulit Pisang Fermentasi + Bungkil Kelapa + Feed Supplement

Hasil penelitian ini memperlihatkan bahwa meskipun penggunaan tepung kulit pisang kepok fermentasi + bungkil kelapa + feed supplement menurunkan berat dan persentase karkas utuh (whole carcass) ayam broiler, penurunan tersebut hanya terjadi pada bagian punggung (back) dan sayap (wings) yang nilai ekonomisnya lebih rendah, sedangkan bagian dada (breast) yang nilai ekonomisnya lebih tinggi meningkat. Hal ini menunjukkan bahwa pemberian tepung kulit pisang kepok fermentasi + bungkil kelapa + feed supplement memberi efek yang bagus terhadap pertambahan berat dada ayam broiler. Hal ini diduga adanya peranan feed supplement di dalam ransum-ransum substitusi. Feed supplement yang digunakan mengandung mineral (Mn, Fe, Zn, Co, I), vitamin $\left(\mathrm{A}, \mathrm{D}, \mathrm{E}, \mathrm{K}, \mathrm{C}, \mathrm{B}_{1}, \mathrm{~B}_{2}, \mathrm{~B}_{12}\right.$, niacin, panthothenat), dan asam amino (methionine dan lysine). Berdasarkan Murtidjo (1992), feed supplement yang banyak dipergunakan dalam ransum unggas biasanya bertujuan untuk melengkapi kekurangan asam amino, vitamin, dan mineral. Senyawa-senyawa ini sangat berperan dalam metabolisme tubuh.

\section{Berat dan Persentase Organ Giblet Ayam Broiler}

Giblet merupakan bagian dari organ tubuh ayam yang masih edibel (dapat dikonsumsi), yang terdiri dari hati, rempela, dan jantung. Dalam perdagangan komersil, hati, rempela, dan jantung disatukan dalam satu kemasan, dan dimasukkan ke dalam kemasan karkas sehingga merupakan bagian dari penyediaan karkas. Berat dan persentase organ giblet ayam broiler yang diberi perlakuan tepung kulit pisang kepok fermentasi + bungkil kelapa + feed supplement diperlihatkan pada Tabel 5.

Hasil sidik ragam memperlihatkan bahwa pemberian tepung kulit pisang kepok fermentasi + bungkil kelapa + feed supplement selama periode finisher tidak berpengaruh nyata $(\mathrm{P}>0,05)$ terhadap berat dan persentase organ-organ giblet ayam broiler. Rataan persentase bobot organ giblet ayam broiler dalam penelitian ini termasuk dalam batas normal. Hal ini menunjukkan bahwa tepung kulit pisang kepok fermentasi + bungkil kelapa + feed supplement tidak memberikan pengaruh negatif terhadap organ-organ giblet ayam broiler.

Hati berfungsi, antar lain, untuk membantu dalam metabolisme karbohidrat, lemak, protein, zat besi, sekresi empedu, detoksifikasi, pembentukan sel darah merah, dan metabolisme, serta penyimpanan vitamin (Ressang, 1998). Adanya zat toksit dalam ransum ataupun air minum dapat mengakibatkan pembesaran hati (Ressang, 1998). Rataan persentase bobot hati ayam broiler dari semua perlakuan dalam penelitian ini berkisar 1,99-2,59\%, sesuai dengan laporan Nickel et al. (1977), yaitu 1,7-2.3\%. Ini menunjukkan bahwa dalam tepung kulit pisang kepok fermentasi tidak mengandung zat-zat toksit atau senyawa-senyawa yang ada dalam bahan tersebut masih dapat ditolerir oleh ayam broiler 
sampai level penggunaan $10 \%$ dalam ransum selama pemberian periode finisher (3-5 minggu).

Tabel 6. Berat dan Persentase Organ Giblet Ayam Broiler yang Diberi Perlakuan Tepung Kulit Pisang Kepok Fermentasi + Bungkil Kelapa + Feed Supplement

\begin{tabular}{|c|c|c|c|c|c|c|}
\hline \multirow[t]{2}{*}{ Giblet } & & \multicolumn{5}{|c|}{$\begin{array}{c}\text { Pemberian Tepung Kulit Pisang Kepok Fermentasi + } \\
\text { Bungkil Kelapa }+ \text { Feed Supplement }\end{array}$} \\
\hline & & $\mathrm{P}_{1}$ & $\mathrm{P}_{2}$ & $\mathrm{P}_{3}$ & $\mathrm{P}_{4}$ & $\mathrm{P}_{5}$ \\
\hline \multirow[t]{2}{*}{ Hati (liver) } & (g) & $44,50 \pm 8,70$ & $46,88 \pm 9,34$ & $37,00 \pm 5,53$ & $38,63 \pm 7,17$ & $43,00 \pm 6,55$ \\
\hline & $(\%)$ & $2,44 \pm 0,76$ & $2,59 \pm 0,46$ & $1,99 \pm 0,31$ & $2,06 \pm 0,30$ & $2,40 \pm 0,39$ \\
\hline \multirow[t]{2}{*}{ Jantung (heart) } & (g) & $6,50 \pm 1,93$ & $5,50 \pm 1,31$ & $5,63 \pm 1,30$ & $5,00 \pm 0,76$ & $5,25 \pm 0,89$ \\
\hline & $(\%)$ & $0,36 \pm 0,14$ & $0,30 \pm 0,06$ & $0,30 \pm 0,08$ & $0,27 \pm 0,03$ & $0,29 \pm 0,04$ \\
\hline \multirow[t]{2}{*}{ Rempela (gizzard) } & (g) & $31,50 \pm 10,14$ & $30,25 \pm 3,92$ & $31,63 \pm 3,62$ & $31,63 \pm 4,47$ & $30,13 \pm 5,44$ \\
\hline & $(\%)$ & $1,67 \pm 0,46$ & $1,67 \pm 0,14$ & $1,70 \pm 0,19$ & $1,69 \pm 0,20$ & $2,85 \pm 1,99$ \\
\hline
\end{tabular}

Peranan jantung adalah sebagai pemompa darah dalam sistem transportasi atau sirkulasi tubuh (Ressang, 1998). Adanya akumulasi racun pada otot jantung dapat mengakibatkan pembesaran jantung (Frandson, 1992). Rataan persentase bobot jantung ayam broiler dari semua perlakuan dalam penelitian ini berkisar $0,27-0,36 \%$, tidak jauh berbeda dengan laporan Ressang (1998), yaitu 0,50-1,42\%. Ini memperkuat bahwa pemberian tepung kulit pisang kepok fermentasi sampai level $10 \%$ tidak memperlihatkan adanya dampak pemberatan kerja jantung ayam broiler dari senyawa-senyawa yang ada dalam bahan tersebut selama pemberian periode finisher (3-5 minggu).

Hasil penelitian ini memperlihatkan ayam-ayam yang diberi ransum yang mengandung tepung kulit pisang kepok fermentasi + bungkil kelapa cenderung memiliki persentase rempela lebih tinggi. Rempela (gizzard) sangat berperan dalam proses pencernaan unggas untuk memperkecil ukuran partikel makanan dengan cara menggiling dan memecahnya menjadi lebih kecil (Pond et al., 1995). Aktivitas gizzard semakin meningkat dengan semakin sulit makanan dicerna, menyebabkan ukurannya bertambah (Kismono, 1986). Namun demikian, rataan persentase gizzard ayam broiler dari semua perlakuan dalam penelitian ini berkisar 1,67-2,85\%, tidak jauh berbeda dengan yang dilaporkan oleh Suprijatna et al. (2008), yaitu 1,6-2,3\%.
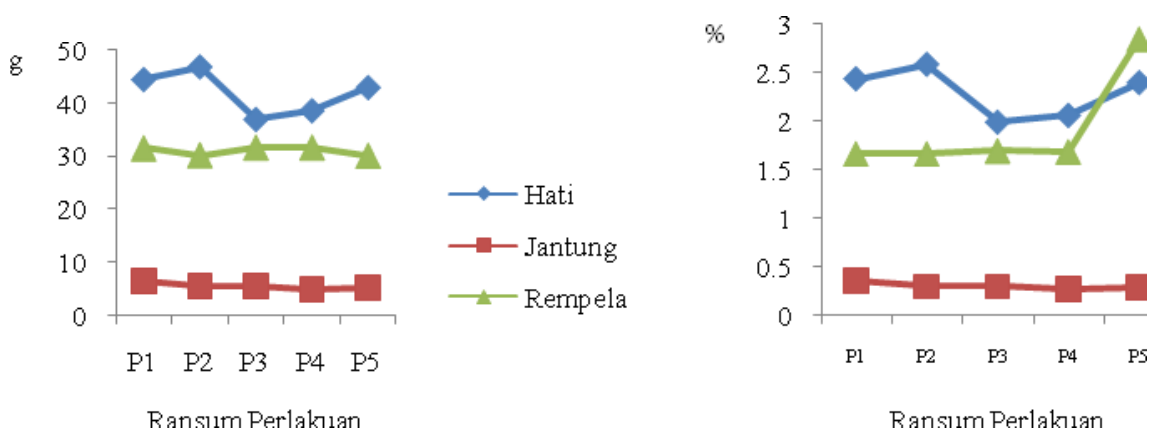

Gambar 3. Berat dan Persentase Organ Giblet Ayam Broiler dari Tiap Pemberian Tepung Kulit Pisang Kepok Fermentasi + Bungkil Kelapa + Feed Supplement 


\section{KESIMPULAN DAN SARAN}

\section{Kesimpulan}

Berdasarkan hasil penelitian yang telah dilakukan dapat disimpulkan :

1. Ransum komersil ayam broiler dapat disubstitusi dengan tepung kulit pisang kepok fermentasi sebanyak 10\% ditambah bungkil kelapa 6\% dan feed supplement $1 \%$ selama periode finisher tanpa berpengaruh nyata terhadap bobot hidup dan karkas ayam broiler, akan tetapi, persentase karkas menurun secara nyata $(\mathrm{P}<0,05)$.

2. Penggunaan tepung kulit pisang kepok fermentasi + bungkil kelapa + feed supplement cenderung meningkatkan persentase dada dan menurunkan persentase punggung ayam broiler.

3. Penggunaan tepung kulit pisang kepok fermentasi + bungkil kelapa + feed supplement tidak berpengaruh nyata $(\mathrm{P}>0,05)$ terhadap berat dan persentase organ giblet (hati, rempela, dan jantung), meskipun rempela agak lebih tinggi, ukurannya masih termasuk normal.

\section{Saran}

Sebaiknya penggunaan tepung kulit pisang fermentasi kepok fermentasi di dalam ransum unggas tidak lebih dari 5\%, karena akan menurunkan berat dan persentase karkas ayam broiler. Perlu dilakukan penelitian lanjut tentang penggunaan tepung kulit pisang fermentasi, misalnya, pada ransum itik, ayam arab, dan ayam kalasan.

\section{DAFTAR PUSTAKA}

Budiansyah, A. 2010. Performan ayam ayam pedaging yang diberi ransum yang mengandung bungkil kelapa yang difermentasi ragi tape sebagai pengganti sebagian ransum komersial. Jurnal Ilmiah Ilmu-Ilmu Peternakan 13 (50): 260-268.

Frandson, R. D. 1992. Anatomi dan Fisiologi Ternak. Alih Bahasa oleh B. Srigandono dan Koen Praseno. Gadjah Mada University Press, Yogyakarta.

Hartadi, H., S. Reksohadiprodjo, S. Lebdosukojo, dan A. D. Tillman. 1980. Tabel-tabel dari Komposisi Bahan Makanan Ternak untuk Indonesia (Tables of Feed Composition for Indonesia). The International Feedstuff Institute. Utah Agricultural Experiment Station. Utah State University, Logan, Utah.

Kismono, S. S. 1986. Toleransi Ayam Broiler terhadap Kandungan Serat Kasar, Serat Detergent Asam, Lignin dan Silika dalam Ransum yang Mengandung Tepung Daun Alang-Alang. Disertasi. Fakultas Pascasarjana Institut Pertanian Bogor, Bogor.

Koni, T. N. I., A. Paga, dan T.A. Foenay. 2006. Substitusi Jagung dengan Campuran Kulit Pisang dan Ampas Kelapa Dalam Ransum Ayam Pedaging. Laporan Hasil Penelitian Politani, Kupang.

Koni, T.N.I. 2009. Pemanfaatan Tepung Kulit Pisang Hasil Fermentasi dengan Jamur Tempe (Rhyzopus oligosporus) dalam Ransum terhadap Pertumbuhan Broiler. Thesis S2 Universitas Nusa Cendana, Kupang.

2013. Pengaruh pemanfaatan kulit pisang yang difermentasi terhadap karkas broiler. JITV 18 (2): 153-157.

McDonald, P., R. A. Edwards, and J. F. D. Greenhalgh. 1994. Animal Nutrition. $4^{\text {th }}$ Ed. Longman Scientific and Technical.

Murtidjo, B. A. 1992. Pedoman Meramu Pakan Unggas. Kanisius, Yogyakarta. 2003. Pedoman Beternak Ayam Broiler. Kanisius, Yogyakarta.

Nickel, R. A., A. Schummer, E. Seiferie, W. G. Siller, and R. A. L. Wight. 1977. Anatomy of the Domestic Birds. Verlag Paul Parey, Berlin. 
Ressang, A. A. 1998. Patologi Khusus Veteriner. Gadjah Mada Press, Yogyakarta.

Shahin, K. A. dan F. A. Elazeem. 2005. Effects of breed, sex and diet and their interactions on carcass composition and tissue weight distribution of broiler chickens. Arch Tierz Dummerstorf 48: 612-626.

Soeparno, 2009. Ilmu dan Teknologi Daging. Gadjah Mada University Press, Yogyakarta.

Steel, R. G. D. dan J. H. Torrie. 1993. Prinsip dan Prosedur Statistika (Pendekatan Biometrik) Penerjemah B. Sumantri. Gramedia Pustaka Utama, Jakarta.

Sudaryani, T. dan H. Santosa, 2003. Pembibitan Ayam Ras. Cet. ke-7. Penebar Swadaya, Jakarta.

Suprijatna, E., U. Atmomarsono, dan R. Kartasudjana. 2008. Ilmu Dasar Ternak Unggas. Penebar Swadaya, Jakarta.

Wahyu, J. 1992. Ilmu Nutrisi Unggas. Cet. ke-3. Gadjah Mada University Press, Yogyakarta.

\section{UCAPAN TERIMAKASIH}

Penulis menyampaikan terima kasih yang sebesar-besarnya kepada Yeyen Safitri, Syairazi dan Syafriadi atas kerjasamanya yang baik selama penelitian serta semua pihak yang turut membantu dalam penelitian ini. 